\title{
PREDICTORS OF INDUSTRY 4.0 TECHNOLOGIES AFFECTING LOGISTIC ENTERPRISES' PERFORMANCE: INTERNATIONAL PERSPECTIVE FROM ECONOMIC LENS
}

\author{
Beata ŚLUSARCZYK (D) 1,2*, Manuela TVARONAVIČIENE் (D) 3, \\ Adnan UL HAQUE ${ }^{\text {DD }}{ }^{5}$, Judit OLÁH (D) 6,7 \\ ${ }^{1}$ Faculty of Management, Czestochowa University of Technology, Częstochowa, Poland \\ ${ }^{2}$ DHET-NRF South African Research Chair in Entrepreneurship Education, College of Business \\ and Economics, University of Johannesburg, Johannesburg, South Africa \\ ${ }^{3}$ Faculty of Business Management, Vilnius Gediminas Technical University, Vilnius, Lithuania \\ ${ }^{4}$ Department of Strategic Management, General Jonas Žemaitis Military Academy of Lithuania, \\ Vilnius, Lithuania \\ ${ }^{5}$ Business Management Faculty, Yorkville University, Yorkville, Canada \\ ${ }^{6}$ Faculty of Economics and Business, University of Debrecen, Debrecen, Hungary \\ ${ }^{7}$ TRADE Research Entity, Faculty of Economic and Management Sciences, \\ North-West University, Vanderbijlpark, South Africa
}

Received 26 April 2020; accepted 14 June 2020

\begin{abstract}
This study examines the influence of the fourth industrial revolution on global and national economies by considering the case of Hungary, Canada and Poland. The research compares local logistic business to gain insight about the implementation of Industry 4.0 practices through exploring existing limited knowledge, preparing staff for challenges, implementation barriers, recognizing potentials and implications of Industry 4.0. Using mixed sampling strategies, we gathered data from 180 logistic enterprises (60 each in considered economies) and established the multi-predictors to investigate the relationship between Industry 4.0 technologies and performance of enterprises. Results revealed that all considered predictors are statistically significant in affecting the impact of Industry 4.0 technologies on the performance of enterprises in all three economies. However, the magnitude of impact differs to some extent. The authors propose recommendations for implications of Industry 4.0 technologies.
\end{abstract}

Keywords: Industry 4.0, national and global economies, economic perspective, logistics enterprises' performance.

JEL Classification: L60, O14, M21.

\section{Introduction}

Industry 4.0 concept was created in peculiar geopolitical circumstances, above all, as the attempt of the German government to ease adverse effects of the world economic crisis (of mortgage credits), but also in order to ensure the long-term growth of their economy in new

*Corresponding author. E-mail: beata.slusarczyk@wz.pcz.pl

Copyright (c) 2020 The Author(s). Published by Vilnius Gediminas Technical University

This is an Open Access article distributed under the terms of the Creative Commons Attribution License (http://creativecommons. org/licenses/by/4.0/), which permits unrestricted use, distribution, and reproduction in any medium, provided the original author and source are credited. 
circumstances. For the first time, the term "Industry 4.0" (Industrie 4.0) appeared in November 2011 in the article printed by the German government, which resulted from the initiative concerning the high-tech strategy for 2020 (Zhou et al., 2015; de Sousa Jabbour et al., 2018; Hariharasudan \& Kot, 2018).

Nowadays, the term Industry 4.0, referring to the Fourth Industrial Revolution, with which the digital transformation of the production (Lasi et al., 2014; Prause \& Atari, 2017; Batkovskiy et al., 2019; Nagy et al., 2018), refers to the widely accepted concept of the development, but with pressure on the development and also vertical and horizontal integration of small and medium organizations orientated at the technology in the processing industry.

As Terziyan et al. (2018) point, the era of Industry 4.0 offers above all the new vision of the functioning of the company: production, services delivery, managing the assets and the conducting of business activities. Pereira and Romero (2017) add that Industry 4.0 offers enormous potential in many areas. Its implementation will affect the entire value chain, simplify manufacturing and engineering processes, improve the quality of products and services, optimize relationships between customers and organizations, provide new business opportunities and economic benefits by changing educational requirements and the current operating environment.

Notable technological achievements resounded, causing so-called industrial revolutions which caused significant transformations in the structure and production management.

The invention of the steam engine strengthened the first industrial revolution in England in the first half of the 18th century (Lu, 2017). Mechanical production using water and steam energy in the cottage industry replaced handicrafts. The second industrial revolution broke out in Europe and the United States in the second half of the 19th century. Mass production and replacement of steam with chemical or electrical energy are essential characteristics of this revolution. To meet the growing demand, industrialists introduced some sorts of technology in the industry and the mechanisation, such as a production line with an automatic drive to increase productivity. During this period, many management processes developed, which allowed to increase the productivity and efficiency of production.

Division of labour, in which each employee performs a portion of all work, increases productivity (Zezulka et al., 2016; Mohelska \& Sokolova, 2018; Laužikas \& Miliūtè, 2020). The first two industrial revolutions increased the well-being of workers and led to urbanization. Advances in IT and electronics in the late 1970s provided more opportunities to optimize production. Production automation, known as programmable logic control systems, increases efficiency and improves quality. It marks the beginning of a third revolution in production (Müller et al., 2018). The forthcoming Fourth Industrial Revolution often referred to as Industry 4.0, is bringing about rapid and fundamental change. Digital manufacturing, network communication, the application of computer and automation technologies, as well as the deployment of many other vital achievements is the basic features of it (Zhou et al., 2015; Yeh, 2017). This new industrial paradigm includes a set of technological transformations such as CPS (Digital Physics Systems), Internet of Things (IoT) and Services (IoS), Intelligent Robotics, Big Data, Cloud Manufacturing and Augmented Reality. It will affect both products and processes, leading to increased work efficiency and productivity in firms that will adopt such technologies (Schmidt et al., 2015; Rao \& Prasad, 2018; Glistau \& Coello Machado, 2018). Besides, Industry 4.0 will bring about fundamental changes in the manufacturing and manufacturing sectors, have a significant impact on all value chains and provide 
new opportunities for improving business models, manufacturing technologies, job creation and work organization.

Industry 4.0 aims to achieve higher levels of operational and production efficiency through higher levels of automation.

Moreover, leading features of this concept are the digitization, the optimization and the personalization of the production; the automation and the adaptation; human-machine interaction (HMI); services with value-added and the company as well as automatic data exchange and communication (Roblek et al., 2016; Magruk, 2016). These features are not only strongly correlated with Internet technologies and advanced algorithms, but also show that Industry 4.0 is an industrial process of adding the value and knowledge management.

The phenomenon of the fourth industrial revolution involves three features (Paprocki, 2016):

- Universal digitization and providing the permanent intercommunication of persons between oneself, persons with devices and of devices between oneself;

- More and more often implemented disruptive innovations which let for irregular increasing the efficiency and effectiveness of functioning of the social-economic system;

- Achieving such a development of machines, in which machines could gain the ability for the autonomous behaviour thanks of use of the "artificial intelligence" in their guidance process.

Technologies characteristic for the 4th industrial revolution can influence the way of production, as well as for perceiving the value of the products by customers. Designed products will have a unique electronic identification in order to track their life cycle, and it will enable the data collection concerning their use. Thanks to that, enterprises will be able to correct the adaptation of products to users requirements. Moreover, connections between machines, devices and elements of the supply chain with shared information will create the possibility of fast modification of orders priorities (on account of customers' requirements or conservation requirements), of monitoring and controlling the productivity of production lines, tracking supplies, as well as streamlining logistic trails (de Sousa Jabbour et al., 2018; Hofmann \& Rüsch, 2017). In addition, as Barysienè et al. (2015) emphasizes, economic growth in separate sectors of the economy is impossible without transport and logistics companies. Their effective activities generate not only economic but also social benefits.

All mentioned changes connected with the 4th industrial revolution certainly have and will have more and more strong impact for changes in the economy. The article aims to determine the kind and the scale of the influence which the 4th industrial revolution has on the global economy and economies of individual states. Literature analyses of Industry 4.0 influence on the functioning of enterprises of the logistic industry in selected countries.

\section{Industry 4.0 influence on the economy}

The fourth industrial revolution will have such an extensive and multifaceted influence on the global economy, that it will be hard to separate one kind of influence from the second. All essential variables of the macro scale, which we can imagine (GDP, level of investment, consumption, employment, trade, inflation, and others) will change (Schwab, 2017). 
The catalogue of effects of Industry 4.0 for the economy is quite extensive, however, still poorly systematized. Numerous authors focus on diverse aspects of this influence, but at large, they underline positive features. For example, Li et al. (2017) show that the transformation towards Industry 4.0 will let for saving stores, efficiency improvement of the production and after all will cause the growth in the economy. Tjahjono et al. (2017) and Ungerman et al. (2018) show greater flexibility, effectiveness and the productivity as well as higher quality standards as the most significant benefits of the implementation of principles of the concept of Industry 4.0. According to them, it will enable the mass personalization, letting enterprises meet requirements of customers and create the value by permanent leading of new products and services to the market.

Kagermann (2015) emphasizes that the production will become highly elastic, highly productive, and at the same time, up to $50 \%$ more efficient in terms of using resources. It will be possible to produce personalized products at the same cost, as in the case of mass-produced products. Resistance, i.e. the ability to withstand and leave out of interferences caused by economic crises or by the infrastructure breakdown will grow, since much more accurate data will allow for accurate forecasts. Real-time information will facilitate the immediate reaction of severe disturbances, for example, by enabling ad hoc reconfiguration of the value network. This flexibility will enable more effective and faster implementation of measures mitigating potential damage to the economy. Intelligent products will not only control the production process actively but will also provide platforms for new services and innovative business models (De la Hoz-Rosales et al., 2019; Zemlickienė \& Turskis, 2020). Also solving the present shortfall of the skilled labour will be possible, for example, by applying intelligent aid schemes in order to help old hands at their work, what will extend their working life.

Đuričin and Herceg (2018) notice that ICT possibilities as the underlying technology of Industry 4.0 are practically limitless. However, this influence not always will be positive (Zavadskas et al., 2009; Turskis et al., 2012; Zavadskas et al., 2013; Chehabeddine \& Tvaronavičienè, 2020; Plèta et al., 2020). New technology causes the situation, in which "winner takes all", destroying the logic of market forces, and "innovator dilemma" is being transformed into "capitalist dilemma".

Although the majority of analyses of the influence of Industry 4.0 focus on the manufacturing industry, this is not the only field, which can be improved as a result of the application of new technologies (Hashemkhani Zolfani et al., 2013). Production is a principal area of applying the new concept. However, changes will influence all relational areas. It will influence not only local cyber-physical systems and local industrial processes but also the whole value chain, including producers, suppliers and employees. Karacay and Aydin (2018) emphasize that the value creation is not limited to one or two branches of industry, but in fact is present in various sectors, not to say cross-sectoral.

What is more, single infrastructure sectors will be unavoidably merging. As the example, it is possible to show the concept of intelligent vehicle, which enriches the mean of transport by such functionalities, as the autonomous ride based on the artificial intelligence (ICT sector involvement) and electromobility aspect (energy sector involvement). It requires creation of the totality, which will be comprehensive and interacting in the quasi-real-time, in which planning, coordination of investment and compatible business models will undergo crosssectoral. 
Influence of Industry 4.0 and in what way benefits are being carried out, will differ in individual countries and industries. Industries of a high level of products variants, so as car and food industry, will be using the higher level of flexibility, while in industries, in which the pressure is being put on the best quality, so as the production of semiconductors and pharmacists, it is possible to use lowered levels of the mistake.

As it was shown above, the economic abilities of Industry 4.0 are broad and concern both the global economy and individual countries. In final years a few examinations and figures illustrating the value of these new solutions and their impact on the economy were published. Examination conducted by Accenture provides the value of the Internet of Things in such countries as the United States, China, Germany and Great Britain up to 2030. The United States will probably reach the most significant benefits ( 7.1 billion USD), then China (1.8 billion USD), Germany (700 billion USD) and Great Britain (531 billion USD) (Petrillo et al., 2018). Examination conducted examining by German Federal Association of Information Technologies, Telecommunications and New Media (BITKOM eV) points that based on introducing the technology of Industry 4.0 in the six chosen manufacturing sectors up to 2025 German GDP will rise annually by $1.7 \%$ in relations to 2013 . Altogether this potential could sum up to the accumulated increase in GDP by $23 \%$ (78.77 bn EUR) in the period from 2013 to 2025 (Bartodziej, 2017). A report prepared by BCG Much provides more specific information about the potential impact of Industry 4.0 to the German economy. It is concentrated on four crucial areas (Rüssmann et al., 2015):

- Productivity: within 5-10 next years, productivity in all German production sectors will be increased by $90-150$ bn EUR. Increasing the productivity in costs of the conversion will take out from 15 up to $25 \%$ (in case of not-including costs of materials) or from 5 up to $8 \%$ (in case of including costs of materials). However, these values will differ depending on the industry;

- Income rise: the demand of producers for upgraded equipment and new data applications, as well as the demand of consumers for a wider range of more and more personalized products, will cause the additional income rise for about 30 billion EUR annually, that is about $1 \%$ of German GDP;

- Employment: stimulated height will lead to 6\% increase in employment within ten nearest years, however in a short stretch the trend towards greater automation will drive the part of low qualified workers, which perform straight, repeatable tasks, out of the market;

- Investments: adapting production processes to Industry 4.0 will require from German producers to invest about 250 billion EUR within ten next years (about $1-1.5 \%$ of producers income).

A similar report was prepared for Turkey. It results from it that in the productivity the growth from 4 up to $7 \%$ is expected, in case of including costs of materials and from 5 up to $15 \%$ in case of excluding these costs from analysis. Moreover, a growth of income by about 150-200 bn TRY is being forecasted, what will be transferred into the increase in Turkish GDP for more than $1 \%$. However, the size of investment essential to the transformation towards Industry 4.0 within ten next years was determined by authors of the report to about 10-15 bn TRY (about 1-1.5\% of producers incomes) (Öztürk, 2017). 
An examination, which Caruso (2017) quotes, also provides interesting data. It results from it that artificial intelligence in its numerous signs promises to convert bases of the economic growth for countries worldwide: analysis of 12 developed economies (including the United States) showed that to 2035 artificial intelligence could double annual economic growth rates in analysed countries.

Rüssmann and others emphasize that the whole transition towards Industry 4.0 can take 20 years, however within next 5 to 10 years crucial progress will be established and in this period first winners and losers will turn up.

Above data can prove that the potential of Industry 4.0 is undeniable. Since however, in every forecast, a certain degree of uncertainty appears, predicted positive macroeconomic effects, which can accompany the network output along the value chain differ much and their evaluation is difficult for many reasons. Industry 4.0 is not defined uniformly, so it is not explicit. Additionally, we do not talk about single technological innovation, but rather about the connection of different technologies (Shpak et al., 2019).

Taking above into consideration, not everyone agrees that Industry 4.0 indeed will have a positive effect on economic growth. As Schwab (2017) notices, in the matter of the influence of the fourth industrial revolution on economic growth, economists split into two camps. According to techno-optimists technologies and the innovation are found in the crucial "point of inflexion", and soon we will be witnesses to the sudden increase of the productivity and much high economic growth. From the other side, techno-pessimists claim that we are already behind substantial changes associated with the digital revolution and their influence on the productivity increase is no more essential.

Anxieties result largely from the evaluation of the economic health through the measurement of the GDP growth, what is being combined with productivity. Up till now, such a growth in the Internet (information) era do not exist what suggests that the digitization will not bring economic growth, but only economic change, with potentially increased inequality. Main counterarguments are the fact that the growth was not yet carried out or a new measure of the productivity is required, which relies to a lesser degree on the output of physical goods and services but more on creation and simple global distribution of digital goods, including soft goods, so as "data" and "knowledge" (Saniee et al., 2017). Schwab (2017) refers to this second argument in some way, because he emphasizes the need of challenging the measurement of input and output data, based on which the productivity is being measured. Innovative products and services created during the fourth industrial revolution show much higher functionality and quality, but are being delivered to markets, which are different indeed from traditional markets, on which measurements were already being made. Many new products and services are "nonrival". They demonstrate zero marginal costs and reach on very competitive markets through digital platforms which results in the decline in prices. In such conditions, traditional statistics can become unreliable in including real value increase, since the consumer surplus will not manage to be taken into account in the total sale level and increased profits. Also Brynjolfsson and McAfee (2014) underline the insufficiency of traditional economic indicators (so as the GDP of the total factor productivity - TFP) for the full spectrum of the influence of Industry 4.0 on the economic growth. Moreover, a high probability exists, that Industry 4.0 will contribute to keeping the tendency, in which the structure 
of industrial indices is no longer correspondent to the structure of the GDP what suggests that the stock exchange market no longer reflects the economy (Maresova et al., 2018).

Following are the research hypotheses:

$\mathrm{H1}$ : Limited knowledge related to Industry 4.0 significant differently affects the impact of Industry 4.0 on the logistic enterprises' performance in different types of economies.

H2 Implementation barriers for Industry 4.0 significant differently affects the impact of Industry 4.0 on the logistic enterprises' performance in different types of economies.

H3: Recognition of potential changes related to Industry 4.0 significant differently affect the impact of Industry 4.0 on the logistic enterprises' performance in different types of economies.

H4: Preparing staff for challenges significant differently affects the impact of Industry 4.0 on the logistic enterprises' performance in different types of economies.

H5: Industry 4.0 technologies have a significantly different impact on the logistic enterprises' performance in different types of economies.

\section{Research methodology}

Employing adequate methodology in the research process is a vital feature. One of the essential part of the study is to employ appropriate method (Faizan et al., 2019). Hence, in this cross-sectional research, quantitative deductive research is employed to numerically expresses the relationship between research variables via following the work of earlier research studies (Haque et al., 2019; Ślusarczyk \& Haque, 2019; Girdzijauskaite et al., 2019). In other words, the factual truth (quantitative aspect) is preferred over useful truth (qualitative perspective) to attain mathematical objectivity. Based on the Likert scale, a survey was developed to gather data. The biases are essential to be avoided in research. Thus, it is essential to have equal and fair representation of respondents (Haque et al., 2018), thus, by employing similar approach, we mixed several different sampling strategies including referral, purposive, area-cluster and convenience sampling techniques to have fair and equal representation in all three countries. Furthermore, networking and gatekeepers' strategies were employed to circulate the online survey among the targeted sector. Since in the absence of no availability of adequate sampling framework. Therefore, purposive sampling was mainly used while area cluster was preferred over stratified sampling so that there is fair and equal representation. Combining and executing different sampling strategies are useful and effective in the attainment of appropriate response from a large population (Ślusarczyk \& Haque, 2019).

Since we targeted the logistic enterprises using Industry 4.0 technologies, therefore, we decided to have one response from the management per company, and as a result, we reached 180 responses (60 in each country). In order to decide upon the probably acceptable sample size, we employed LeBlanc (2004) formula of marginal error (M.E), by adopting the strategy

of Haque et al. (2019) and Urbanski and Haque (2020).
LeBlanc proposed formula of marginal error (M.E $\left.=\frac{z \sqrt{\hat{p}(1-\hat{p})}}{n}\right)$ in 2004 to determine minimum acceptable sample size in research (Haque et al., 2019). Interestingly, LeBlanc (2004) argued that the marginal error differs in applied and social sciences. The margin of 
error \pm 3 in applied sciences whereas \pm 4 in social sciences is acceptable for determining sufficient sample size in studies. Since, this is a social science research, therefore, \pm 4 was preferred over \pm 3 . Below is the determination of sample size:

$z=1.96$ with $95 \%$ confidence,

M.E $= \pm 4 \%(0.04)$,

$n=$ Sample Size,

$\hat{p}=$ prior judgement of the correct value of $p$ (Probability to have more than $8 \%$ of population in each region).

$$
\begin{aligned}
& \text { M.E }=\frac{z \sqrt{\hat{p}(1-\hat{p})}}{n} \Rightarrow \mathbf{n}=\frac{z \sqrt{\hat{p}(1-\hat{p})}}{M . E} ; \\
& n=\frac{\hat{p}(1-p) z^{2}}{M \cdot E^{2}} ; \\
& n=\frac{0.08(1-0.92)(1.96)^{2}}{(0.04)^{2}} ; \\
& n=\frac{(0.08 X 0.92) X(1.96 X 1.96)}{0.04 X 0.04} ; \\
& n=\frac{0.0736 \times 3.8414}{0.0016} ; \\
& n=\frac{0.28272704}{0.0016} ; \\
& n=176.70 .
\end{aligned}
$$

Hence, the above obtained value indicates that the minimum sample size required in this study should be 176.7 (round figure $=177$ ) enterprises to reach a logical conclusion. A total 180 respondents (60 from each country) participated in this study so that there is equal and fair representation. According to Haque and Oino (2019), for minimizing the biases, the stratification of major groups of respondents is an effective technique in social science research by having fair representation. Thus, we ensured we have equal and fair representation.

We used SPSS 23.0 for statistical test, and since we considered the multiple predictors within one construct, therefore, we used multiple regression test to determine the impact of predictors on enterprises' performance for numeric expression, following the strategy of Ślusarczyk and Haque (2019). Interestingly, their work had explored the mediating effect of these variables while this study takes a step further to explore the direct impact of considered variables on the enterprises' performance. Moreover, this study takes the economic perspective to explain the Industry 4.0 implications. The strategic approach began at the preliminary research stage with personal visits by the researchers in different organizations in Canada, Hungary, and Poland to observe the trends and operations related to Industry 4.0 technologies. Based on the observation and data, we found these different variables in association with the firm's performance. Thus we further confirmed that literature and preliminary study are aligned to a more considerable extent. The response rate remained healthy and acceptable 
as we have a collective $30 \%$ response rate from a total of 600 questionnaires (200 in each country) circulated. In total, four attempts an equal number of responses were gathered from all targeted economies. Imran and others' (2018)

conceptual framework for Industry 4.0 was employed for the operationalization of constructs. It also reflects the reliability and validity of the constructs.

The ethical considerations were maintained by disclosing the purpose of research to the participants, providing the option to leave the survey at any time, no monetary reward against participation, using the share experiences and opinions only for the academic purpose, and maintaining anonymity of the participants at all stages of research.

\section{Results, findings and discussions}

\section{Descriptive statistics}

The descriptive analysis showed that the majority of the limited liability companies participated from Hungary (58\%) and Poland (56\%) while limited joint-stock partnership from Canada (43\%). Interestingly, in all three countries, the majority of the participating enterprises had (10-49) employees from Hungary (63\%), Canada (61\%) and Poland (53\%). Transport logistic businesses remain leading profile business in Hungary (74\%), Canada (72\%) and Poland (62\%). Lastly, majority of the participants were familiar with the concepts of Industry 4.0 features and were in the process of planning to launch it within their respective company Hungary (65\%), Canada (62\%) and Poland (57\%). All this information is given in Table 1.

Table 1. Descriptive variables (source: author's calculations based on the collected data)

\begin{tabular}{|c|c|c|c|c|}
\hline Component & Country & Category & Frequency & $\%$ \\
\hline \multirow{3}{*}{$\begin{array}{l}\text { Organizational } \\
\text { and legal form } \\
\text { of company }\end{array}$} & Hungary & $\begin{array}{l}\text { Joint-stock company } \\
\text { Limited liability company } \\
\text { General partnership } \\
\text { Limited liability partnership } \\
\text { Limited partnership } \\
\text { Limited joint-stock partnership } \\
\text { Sole proprietorship }\end{array}$ & $\begin{array}{l}03 \\
35 \\
12 \\
03 \\
02 \\
04 \\
01\end{array}$ & $\begin{array}{c}5 \\
58 \\
20 \\
5 \\
3 \\
6 \\
3\end{array}$ \\
\hline & Canada & $\begin{array}{l}\text { Joint-stock company } \\
\text { Limited liability company } \\
\text { General partnership } \\
\text { Limited liability partnership } \\
\text { Limited partnership } \\
\text { Limited joint-stock partnership } \\
\text { Sole proprietorship }\end{array}$ & $\begin{array}{l}12 \\
07 \\
02 \\
03 \\
06 \\
26 \\
04\end{array}$ & $\begin{array}{c}20.0 \\
11.6 \\
3.4 \\
5.0 \\
10.0 \\
43.4 \\
6.6\end{array}$ \\
\hline & Poland & $\begin{array}{l}\text { Joint-stock company } \\
\text { Limited liability company } \\
\text { General partnership } \\
\text { Limited liability partnership } \\
\text { Limited partnership } \\
\text { Limited joint-stock partnership } \\
\text { Sole proprietorship }\end{array}$ & $\begin{array}{l}05 \\
34 \\
09 \\
03 \\
02 \\
04 \\
03\end{array}$ & $\begin{array}{c}8.3 \\
56.3 \\
15.0 \\
5.0 \\
3.6 \\
6.7 \\
5.0\end{array}$ \\
\hline
\end{tabular}


Continue of Table 1

\begin{tabular}{|c|c|c|c|c|}
\hline Component & Country & Category & Frequency & $\%$ \\
\hline \multirow{3}{*}{$\begin{array}{l}\text { Number } \\
\text { of employees }\end{array}$} & Hungary & $\begin{array}{l}10-49 \\
50-249 \\
250 \text { or more }\end{array}$ & $\begin{array}{l}38 \\
13 \\
09 \\
\end{array}$ & $\begin{array}{l}63.3 \\
21.3 \\
15.2 \\
\end{array}$ \\
\hline & Canada & $\begin{array}{l}10-49 \\
50-249 \\
250 \text { or more }\end{array}$ & $\begin{array}{l}37 \\
13 \\
10\end{array}$ & $\begin{array}{l}61.6 \\
21.3 \\
16.2\end{array}$ \\
\hline & Poland & $\begin{array}{l}10-49 \\
50-249 \\
250 \text { or more }\end{array}$ & $\begin{array}{l}32 \\
17 \\
11\end{array}$ & $\begin{array}{l}53.3 \\
28.4 \\
18.3\end{array}$ \\
\hline \multirow{3}{*}{$\begin{array}{l}\text { Leading } \\
\text { business } \\
\text { profile }\end{array}$} & Hungary & $\begin{array}{l}\text { Transport } \\
\text { Warehousing and inventory management } \\
\text { Forwarding } \\
\text { Packing and packaging } \\
\text { Information services: providing information } \\
\text { for planning, coordination, control of logistics } \\
\text { processes } \\
\text { Third-Party Logistics (3PL) } \\
\text { Supply chain management }\end{array}$ & $\begin{array}{l}44 \\
02 \\
04 \\
03 \\
02 \\
05\end{array}$ & $\begin{array}{c}73.6 \\
3.3 \\
6.6 \\
5.0 \\
3.3 \\
8.2\end{array}$ \\
\hline & Canada & $\begin{array}{l}\text { Transport } \\
\text { Warehousing and inventory management } \\
\text { Forwarding } \\
\text { Packing and packaging } \\
\text { Information services: providing information } \\
\text { for planning, coordination, control of logistics } \\
\text { processes } \\
\text { Third-Party Logistics (3PL) } \\
\text { Supply chain management }\end{array}$ & $\begin{array}{l}43 \\
03 \\
05 \\
03 \\
03 \\
03\end{array}$ & $\begin{array}{c}71.6 \\
5.0 \\
8.4 \\
5.0 \\
5.0 \\
5.0\end{array}$ \\
\hline & Poland & $\begin{array}{l}\text { Transport } \\
\text { Warehousing and inventory management } \\
\text { Forwarding } \\
\text { Packing and packaging } \\
\text { Information services: providing information } \\
\text { for planning, coordination, control of logistics } \\
\text { processes } \\
\text { Third-Party Logistics (3PL) } \\
\text { Supply chain management }\end{array}$ & $\begin{array}{l}37 \\
08 \\
06 \\
04 \\
02 \\
03\end{array}$ & $\begin{array}{c}61.7 \\
13.4 \\
10.0 \\
6.6 \\
3.3 \\
5.0\end{array}$ \\
\hline $\begin{array}{l}\text { Concept of } \\
\text { Industry } 4.0\end{array}$ & Hungary & $\begin{array}{l}\text { No, I have never heard of it } \\
\text { Yes, I have heard of it, but I do not know what } \\
\text { it is characterized by } \\
\text { Yes, I know the details characterizing the } \\
\text { concept } \\
\text { Yes, I know the details characterizing the } \\
\text { concept and we are planning to launch it in our } \\
\text { company } \\
\text { Yes, we are launching its assumptions/ } \\
\text { technologies in our company }\end{array}$ & $\begin{array}{l}08 \\
04 \\
07 \\
39 \\
02\end{array}$ & $\begin{array}{c}13.4 \\
6.6 \\
11.6 \\
65.0 \\
3.6\end{array}$ \\
\hline
\end{tabular}


End of Table 1

\begin{tabular}{|c|c|c|c|c|}
\hline Component & Country & Category & Frequency & $\%$ \\
\hline \multirow{2}{*}{$\begin{array}{l}\text { Concept of } \\
\text { Industry } 4.0\end{array}$} & Canada & $\begin{array}{l}\text { No, I have never heard of it } \\
\text { Yes, I have heard of it, but I do not know what } \\
\text { it is characterized by } \\
\text { Yes, I know the details characterizing the } \\
\text { concept } \\
\text { Yes, I know the details characterizing the } \\
\text { concept and we are planning to launch it in our } \\
\text { company } \\
\text { Yes, we are launching its assumptions/ } \\
\text { technologies in our company }\end{array}$ & $\begin{array}{l}09 \\
05 \\
08 \\
37 \\
01\end{array}$ & $\begin{array}{c}15.0 \\
8.4 \\
13.4 \\
61.6 \\
1.6\end{array}$ \\
\hline & Poland & $\begin{array}{l}\text { No, I have never heard of it } \\
\text { Yes, I have heard of it, but I do not know what } \\
\text { it is characterized by } \\
\text { Yes, I know the details characterizing the } \\
\text { concept } \\
\text { Yes, I know the details characterizing the } \\
\text { concept and we are planning to launch it in our } \\
\text { company } \\
\text { Yes, we are launching its assumptions/ } \\
\text { technologies in our company }\end{array}$ & $\begin{array}{l}10 \\
06 \\
07 \\
34 \\
03\end{array}$ & $\begin{array}{c}16.7 \\
10.0 \\
11.6 \\
56.7 \\
5.0\end{array}$ \\
\hline
\end{tabular}

Table 2. Model summary a,c

\begin{tabular}{|c|c|c|c|c|}
\hline Model & $\mathrm{R}$ & $\mathrm{R}$ Square & Adjusted R Square & Std. Error of the Estimate \\
\hline 1 & $0.652^{\mathrm{b}}$ & 0.641 & 0.558 & 1.16754 \\
\hline 2 & $0.647^{\mathrm{b}}$ & 0.635 & 0.556 & 1.28612 \\
\hline 3 & $0.639^{\mathrm{b}}$ & 0.622 & 0.547 & 1.38815 \\
\hline
\end{tabular}

Notes: ${ }^{\text {a }}$ Country: 1 = Hungary, 2 = Canada and 3 = Poland; ${ }^{\mathrm{b}}$ Predictors: (Constant), Limited knowledge, Implementation barriers, Recognition of potential changes, Preparing staff for changes, Industry 4.0 technologies; ${ }^{\mathrm{c}}$ Dependent Variable: Logistic Enterprises' Performance.

Above presented model summary reflects that R2 for all three considered economies is over 0.6 , which means that over $60 \%$ variation in the logistic enterprises' performance is caused by predictors such as limited knowledge, implementation barriers, recognition of potential changes, preparing staff of changes, and introduction of Industry 4.0 technologies. In-depth, it revealed that $64.1 \%$ variation in Hungary, 63.5\% variation in Canada and $62.2 \%$ variation in Poland's enterprise performance caused by the variables in questions (predictors) (Table 2).

The ANOVA model showed that $\mathrm{F}=39.88$ for Hungary, reflecting $39.88 \%$ explanatory power of the model, $\mathrm{F}=38.21$ for Canada means $38.21 \%$ whereas Poland scored $\mathrm{F}=37.31$, reflecting $37.31 \%$ explanatory power (Table 3). Furthermore, the sig value is less than alpha for all considered economies (Hungary $=0.000<0.05$; Canada $=0.000<0.05$; Poland $=$ $0.000<0.05)$, reflecting the value is statistically significant. Thus, the explanatory power of the model is acceptable in all considered economies as over one-third is explained by the model. The model is a good fit. 
Table 3. ANOVA ${ }^{a, b}, a^{\prime} b, a^{\prime \prime} b$

\begin{tabular}{|c|c|c|c|c|c|c|}
\hline & Model & Sum of Squares & Df & Mean Square & $\mathrm{F}$ & Sig. \\
\hline 1 & $\begin{array}{l}\text { Regression } \\
\text { Residual } \\
\text { Total }\end{array}$ & $\begin{array}{l}193.741 \\
379.436 \\
573.177\end{array}$ & $\begin{array}{c}3 \\
177 \\
180\end{array}$ & $\begin{array}{c}39.888 \\
1.945\end{array}$ & 37.943 & $0.000^{c}$ \\
\hline 2 & $\begin{array}{l}\text { Regression } \\
\text { Residual } \\
\text { Total }\end{array}$ & $\begin{array}{l}195.536 \\
373.144 \\
568.680\end{array}$ & $\begin{array}{c}3 \\
177 \\
180\end{array}$ & $\begin{array}{c}38.214 \\
1.921\end{array}$ & 36.293 & $0.000^{\mathrm{c}}$ \\
\hline 3 & $\begin{array}{l}\text { Regression } \\
\text { Residual } \\
\text { Total }\end{array}$ & $\begin{array}{l}196.272 \\
394.541 \\
590.813\end{array}$ & $\begin{array}{c}3 \\
177 \\
180\end{array}$ & $\begin{array}{c}37.218 \\
1.902\end{array}$ & 35.316 & $0.000^{\mathrm{c}}$ \\
\hline
\end{tabular}

Notes: a. Country $=1.0-$ Hungary; $\mathrm{a}^{\prime}$. Country $=2.0-$ Canada; a". Country $=3.0-$ Poland; b. Dependent Variable: Logistic Enterprises' Performance.

Since the R2 (regression) is higher as well as F (explanatory power) is acceptable. Therefore, the model is acceptable, and we measure the multiple regression of the predictors on the dependent variables.

The Figure 1 reflects the multiple regression of predictors affecting the logistic enterprises' performance in contrasting economies. Further statistical expressions are explored in the below following section.

The statistical results revealed that limited knowledge related to Industry 4.0 statistically significant differently affect the impact of Industry 4.0 on the performance of logistic enterprises in different types of economies. Therefore, we do not reject hypothesis 1 . Findings revealed that the impact of Industry 4.0 on the logistic enterprises' performance are statistically significantly different in all three economies (Hungary $=0.001<0.05, \mathrm{p}<\alpha$; Canada $=0.001<0.05, \mathrm{p}<\alpha$; Poland $=0.000<0.05, \mathrm{p}<\alpha$; Table 4). In addition to that, the standardized coefficient variation $\beta=0.041$ in Hungary is higher than Canada $(\beta=0.019)$ and Poland $(\beta=0.029)$, reflecting that limiting knowledge affect the logistic performance higher in Hungary than Canada and Poland. Perhaps, this could be attributed to the level of consumption, investment, employment, inflation, trade, and GDP, which are essential variables of macro scale. Hence, this study supports the earlier work of Schwab (2017). Using the funnel approach, the reasons were explored and found that efficiency in production is an essential part of economic growth for the country. Hence, the present findings hinted towards the well-established fact that economic growth varies in distinctive economies based on the improvement in production efficiency. Therefore this study is aligned with the- work of Li et al. (2017). Furthermore, the present findings support the work of Slusarczyk and Haque (2019) that limited knowledge about Industry 4.0 significantly affects the performance of enterprises is different types of economies.

The present findings also confirmed that statistically implementation barriers for Industry 4.0 significant differently affect the impact of Industry 4.0 practices and logistic enterprise performances in distinctive economies (Hungary $=0.003<0.05, \mathrm{p}<\alpha$; Canada $=0.000<0.05$, $\mathrm{p}<\alpha$; Poland $=0.000<0.05, \mathrm{p}<\alpha$; Table 4). Thus, we do not reject hypothesis 2 . In other words, it is established that implementation barriers related to Industry 4.0 significantly differ in contrasting economies, and therefore the enterprises' performance also affect differently. From the economic perspective, the greater flexibility, effectiveness and productivity, and 

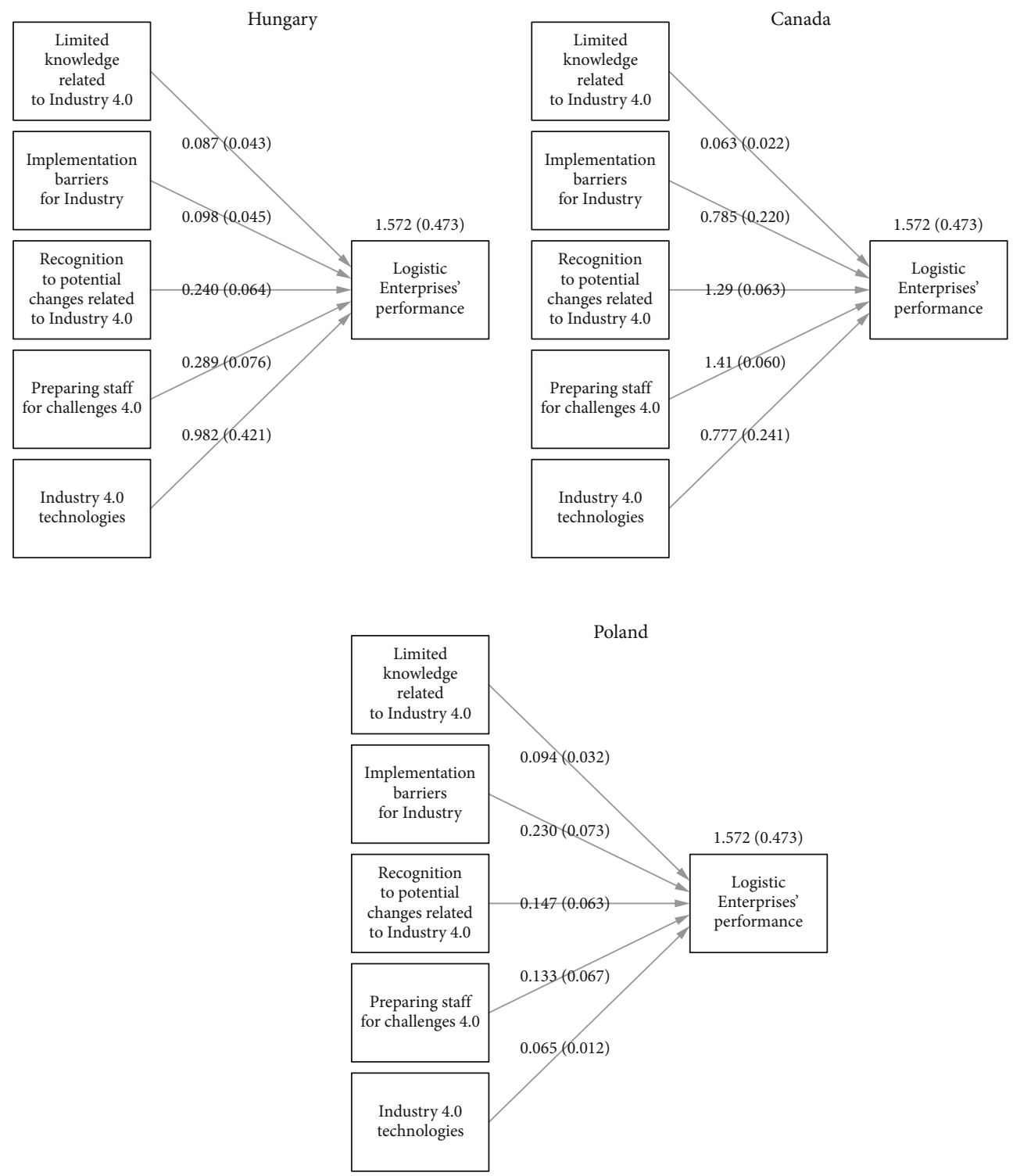

Figure 1. Comparison of predictors affecting enterprises' performance in contrasting economies (multiple regression)

higher quality of standards play a significant role in the implementation process while the mass personalization, meeting customer requirements and value creation that are likely to improve even though Industry 4.0 implementation is significantly hindered because of economic and legal barriers. Thus, the work of B. Tjahjono et al. (2017) is confirmed through present findings. Since the coefficient variation is higher in Poland $(\beta=0.229)$ than Hungary ( $\beta=0.042)$ and Canada $(\beta=0.221)$, thus, implementation barriers are more significantly affecting the enterprises' performance in Poland than in the Hungary and Canada. 
Table 4. Multiple regressions

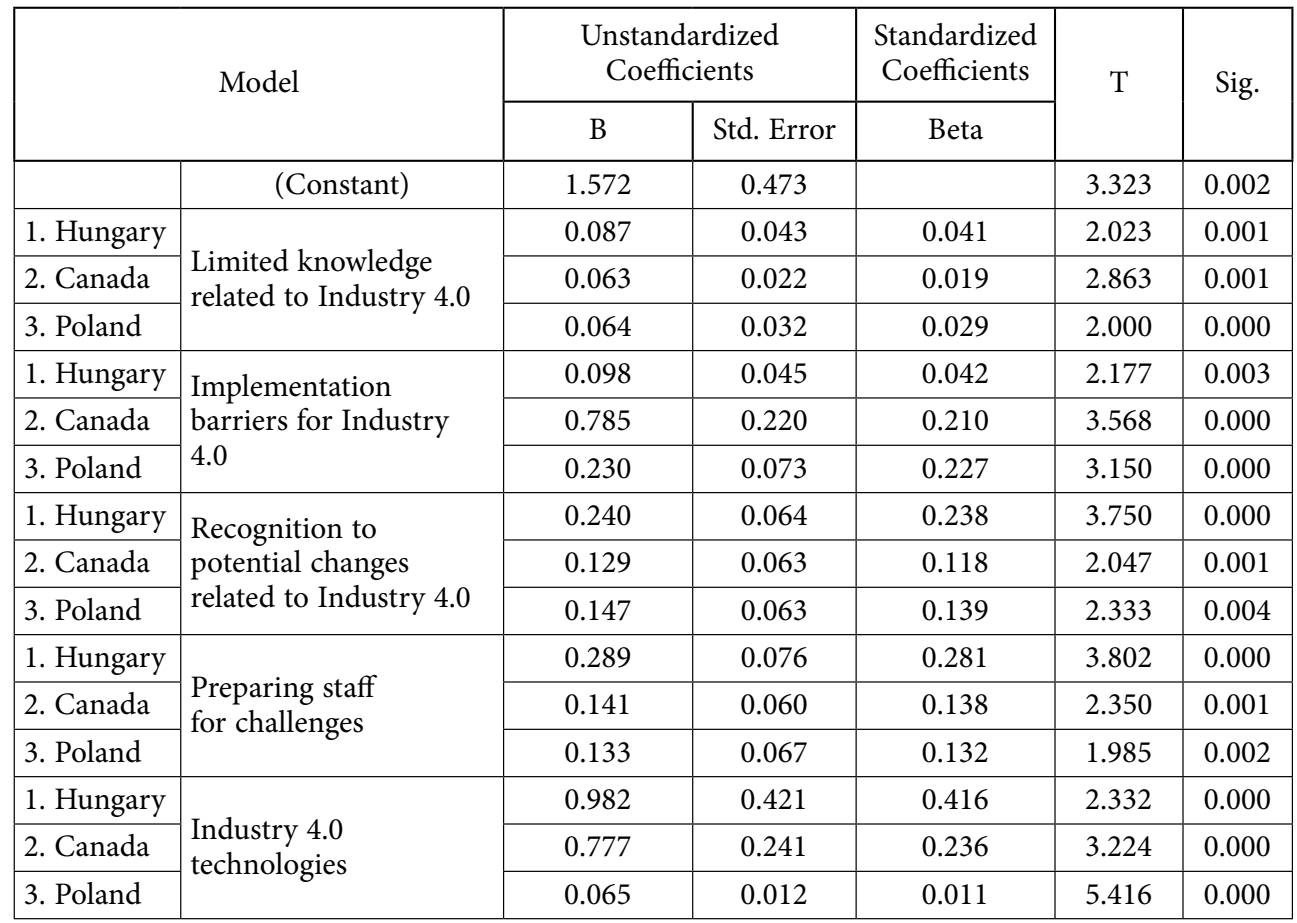

Statistical test revealed that recognition of potential changes interlinked with Industry 4.0 significant differently affect the logistic enterprises' performance in different types of economies (Hungary $=0.000<0.05, \mathrm{p}<\alpha$; Canada $=0.001<0.05, \mathrm{p}<\alpha$; Poland $=0.004<0.05$, $\mathrm{p}<\alpha$; Table 4). Therefore, we do not reject hypothesis 3 . In other words, this study supports the earlier arguments of Ślusarczyk and Haque (2019) and Rodič (2017), that companies with a potential backup strategies in the economic complexities tend to do better because of their potential to recognise the changes regarding Industry 4.0 implementations. Since this study confirmed that such recognition differs for companies operating in differing economies, hence, it indicates that the argument posed by Kagermann (2015) is supported to a larger extent that companies are highly effective in using its resources that are recognizing the potential changes to keep up with high elasticity. Moreover, the same study argued that resistance, which is the efficiency for withstanding and leave out of interferences caused by economic crises or by the infrastructure breakdown, would grow. Hence, the real-time information would be pivotal for the companies to deal with the serious disturbance related to Industry 4.0 implications. The same study confirmed that flexibility would be effective in measuring the mitigating damages for the economy through the ability to recognize potential changes. Therefore, this study is aligned with those findings. Furthermore, coefficient variation in Hungary $(\beta=0.23)$ is higher than the Canada $(\beta=0.11)$ and Poland $(\beta=0.13)$, reflecting that the recognition for potential changes related to Industry 4.0 is higher in Hungary in comparison to the Canada and Poland. 
Present study confirmed that preparing staff for challenges statistically significantly differ in creating the impact of Industry 4.0 on the logistic enterprises' performance in different types of economies (Hungary $=0.000<0.05, \mathrm{p}<\alpha$; Canada $=0.001<0.05, \mathrm{p}<\alpha$; Poland $=$ $0.002<0.05, \mathrm{p}<\alpha$; Table 4). Thus, we do not reject hypothesis 4 . As a result, this study partially supported the work of Slusarczyk and Haque (2019), because their study found mediating role while here it is a more direct effect established through this study. Exploring from the economic perspective, we used a funnel approach to explore the hidden embedded themes and interestingly we found that Đuričin and Herceg (2018) argument that ICT possibilities as the basic technology of Industry 4.0 are practically limitless. Moreover, it is highly effective in preparing staff for the challenges related to Industry 4.0 implementations.

Nevertheless, the same study argued that new technology causes the situation, in which "winner takes all", destroying the logic of market forces, and "innovator dilemma" is being transformed into "capitalist dilemma" (Đuričin \& Herceg, 2018). Hence, the organizations must adequately prepare their staff members to tackle the challenges of Industry 4.0. Since the application of new technologies need a higher focus in all types of sectors rather than confining it to only manufacturing sector, therefore, the proper preparation is highly essential part for the organizations to survive in the complex business environment. The relational areas are significantly affected by the changes, and therefore the organizations need to prepare their staff for the new concepts and its interlinked challenges. Therefore, this study supports the arguments that the preparation of staff would be valuable for the organizations to execute Industry 4.0 technologies in the whole value chains, including producers, suppliers, and employees. Moreover, the present study findings are also supporting the work of Karacay and Aydin (2018) that it is essential to prepare staff for different types of challenges because the value creation is not limited to one or two branches of industry, but in fact is present in various sectors, not to say cross-sectoral. In addition to that the argument is also confirmed that preparing staff for challenges leads to create the totality, which would be comprehensive and interacting in the quasi-real-time, hence, the planning, coordination of investment and compatible business models would undergo cross-sectoral that could be effective in improving firm's performance in different economies through implementing Industry 4.0 technologies. Since the coefficient variation is higher in Hungary $(\beta=0.28)$ than Canada $(\beta=0.13)$ and Poland $(\beta=0.13)$, thus, preparation staff for challenges are more significantly affecting the enterprises' performance in Hungary than in the Canada and Poland.

Lastly, the statistical test confirmed that Industry 4.0 technologies have significant different impact on the logistic enterprises' performance in different types of economies (Hungary $=0.000<0.05, \mathrm{p}<\alpha$; Canada $=0.000<0.05, \mathrm{p}<\alpha$; Poland $=0.000<0.05, \mathrm{p}<\alpha$; Table 4). Therefore, we do not reject hypothesis 5 . This study confirms the work of Haseeb et al. (2019), as we confirmed that Industry 4.0 technologies are significantly affecting the performance of the enterprises. Nevertheless, this study goes one step further by ensuring that this direct relationship between Industry 4.0 and enterprises' performance is explored from different economies. Previously, the economic perspective was missing to explain the reason for correlating.

Furthermore, there was no conclusive evidence regarding the differentially perspective on whether the impact different in its intensity and magnitude within the different economies. 
The present study confirmed that the impact is statistically significant, but it differs in the type of economies in its intensity and magnitude. Continuing in same dimension, the coefficient variation is higher in Hungary $(\beta=0.41)$ than Canada $(\beta=0.23)$ and Poland $(\beta=$ $0.01)$, thus, the magnitude of impact varies in the different economies. As a result, the impact of Industry 4.0 technologies are more significantly affecting the enterprises' performance in Hungary than in the Canada and Poland.

\section{Conclusions}

The present study concludes that all the predictors have a statistically significant impact on the logistic enterprises' performance in different types of economies. This study confirmed that limited knowledge regarding Industry 4.0 varies in its magnitude while creating the impact of Industry 4.0 on the performance. Thus, the present study supports the cited work in the literature section. Drawn conclusion confirms that using the funnel approach, we found that efficiency in production is an essential part of economic growth for the country, irrespective of its economic standing.

Furthermore, we partially confirmed that improvement in the production efficiency varying in types of economies is a result of the economic growth rate. It is further confirmed that limited knowledge about the Industry 4.0 significantly affects the performance of enterprises is different types of economies. Moreover, this study concludes that implementation barriers related to Industry 4.0 significantly differ in contrasting economies, and therefore the enterprises' performance also affect differently. From the economic lens, effectiveness and productivity, higher flexibility, and top quality of standards play a vital role in the implementation process whereas economic and legal barriers. Again, the magnitude and intensity of impact is evident to differ in distinctive types of economies.

The study also concludes that recognition of potential changes interlinked with the Industry 4.0 significant differently affect the logistic enterprises' performance in different types of economies. Thus, we support the earlier cited literature. Such strategic approach enables the organizations to deal with economic complexities. From the economic lens, it is found that the potential use of resources effectively and efficiently is mainly because of the adequate strategies to recognise and deal with economic as well as technological changes in the operating dynamics. We concluded that the effective use of resources is useful in coping with changes. Hence, in other words, higher flexibility enables firm in dealing with the potential challenges in a complex business environment. Furthermore, flexibility is effective in controlling the mitigating damages for the economy through the ability to recognize potential changes. It was found that the recognition of potential changes related to Industry 4.0 is higher in Hungary in comparison to Canada and Poland. In addition to that, preparing staff for challenges statistically significantly differ in creating the impact of Industry 4.0 on the logistic enterprises' performance in different types of economies. Present findings partially supported the work of Slusarczyk and Haque. From the economic lens, it was found that technology is the need and demand of the business world. It is argued and established from the economic grounds that preparing staff for challenges to deal with Industry 4.0 implementation differ in countries, but it does improve the working efficiency of the logistic en- 
terprises. The relational areas are effectively affected by the alterations, and thus it is pivotal for the organizations to prepare their workforce for the new concepts and its interlinked challenges. It is found that higher magnitude for staff preparation in Hungary than Canada and Poland. Finally, this study concludes that Industry 4.0 technologies have a significantly different impact on the logistic enterprises' performance in different types of economies. As a result of this, the earlier work of Haseeb et al. (2019) is confirmed. Further, we built on and found that the direct relationship between Industry 4.0 and enterprises' performance remains significant in different economies. In addition to that, the magnitude is higher in Hungary than Canada and Poland.

Based on the findings, it is recommended that for every logistic enterprise, there should be three dimensions to focus, social, legal and economic perspective. A focus on the one aspect at the expense of others would negatively impact their working efficiency. Nevertheless, the economic stability could be attained when Industry 4.0 technologies are implemented in the framework while keeping both legal and social attributes intact. Furthermore, the logistic firms should ensure that periodically the data is submitted to the statistical data in order to ensure that the economic growth and economic development are aligned while the implementation of Industry 4.0 are regularly monitored. In addition to that, the government should take initiatives to ensure that there are proper seminars, workshops, and mandatory sessions for the logistic enterprises to educate them and provide facilities for installing modern technologies.

The use of Information and Communication Technologies (ICTs) should be promoted to ensure that the economic prosperity is attained through strengthening the networking and shared knowledge. The implementation and execution of Industry 4.0 would bring more fruitful economic rewards and prepare the workforce to understand the implications and overcome the challenges of Industry 4.0. Sharing information and knowledge with internal customers should be made a regular practice so that the human capital in the shape of social and intellectual capital strengthen further by having awareness about Industry 4.0 practices. The economic competitiveness would further attain through improved and well-prepared staff to deal with the environmental challenges, including context, connectedness, and complexities.

Despite our best efforts, there are some limitations in this study that could be overcome by future studies. Hence, we recommend that the future studies shall improve the sample size as 60 per economy is too small for higher generalization. In addition to that, the sampling techniques are subject to self-bias when there is no structural methodological approach. A use of mixed sampling technique creates its own biases. Therefore, we recommend that quota representation should be made by having at least one-third representation of sample from considered economy to attain higher generalization. This study has a higher emphasis on mathematical objectivity, while the hidden embedded useful truth is still under research. It would be effective if the future studies follow the quantitative studies by qualitative studies to provide useful truth. The interviews would further enlighten the insight about Industry 4.0 technologies in the differing economies. All the considered aspects would be useful in gaining more in-depth insight and improved generalizability. 


\section{Author contributions}

BS conceived the study and were responsible for the design and development of the data analysis. BŚ, AH, and JO were responsible for data collection and analysis. AH and MT were responsible for data interpretation. BŚ wrote the first draft of the article.

\section{Disclosure statement}

Authors do not have any competing financial, professional, or personal interests from other parties.

\section{References}

Barysienė, J., Batarlienė, N., Bazaras, D., Čižiūnienė, K., Griškevičienė, D., Griškevičius, A. J., Lazauskas, J., Mačiulis, A., Palšaitis, R., Vasiliauskas, A. V., \& Vasilienė-Vasiliauskienė, V. (2015). Analysis of the current logistics and transport challenges in the context of the changing environment. Transport, 30(2), 233-241. https://doi.org/10.3846/16484142.2015.1046403

Bartodziej, C. J. (2017). The concept industry 4.0. In The concept industry 4.0 (pp. 27-50). Springer Gabler. https://doi.org/10.1007/978-3-658-16502-4_3

Batkovskiy, A. M., Leonov, A. V., Pronin, A. Y., Semenova, E. G., Fomina, A. V., \& Balashov, V. M. (2019). Sustainable development of Industry 4.0: the case of high-tech products system design. Entrepreneurship and Sustainability Issues, 6(4), 1823-1838. https://doi.org/10.9770/jesi.2019.6.4(20)

Brynjolfsson, E., \& McAfee, A. (2014). The second machine age: work, progress, and prosperity in a time of brilliant technologies. W.W. Norton \& Company.

Caruso, L. (2018). Digital innovation and the fourth industrial revolution: epochal social changes? AI \& Society, 33(3), 379-392. https://doi.org/10.1007/s00146-017-0736-1

Chehabeddine, M., \& Tvaronavičienė, M. (2020). Securing regional development. Insights into Regional Development, 2(1), 430-442. http://doi.org/10.9770/IRD.2020.2.1(3)

de la Hoz-Rosales, B., Camacho, J., \& Tamayo, I. (2019). Effects of innovative entrepreneurship and the information society on social progress: an international analysis. Entrepreneurship and Sustainability Issues, 7(2), 782-813. http://doi.org/10.9770/jesi.2019.7.2(1)

de Sousa Jabbour, A. B. L., Jabbour, C. J. C., Foropon, C., \& Godinho Filho, M. (2018). When titans meet-Can industry 4.0 revolutionise the environmentally-sustainable manufacturing wave? The role of critical success factors. Technological Forecasting and Social Change, 132, 18-25. https://doi.org/10.1016/j.techfore.2018.01.017

Đuričin, D., \& Herceg, I. V. (2018). Industry 4.0 and paradigm change in economics and business management. In International Conference on the Industry 4.0 model for Advanced Manufacturing (pp. 37-56). Springer. https://doi.org/10.1007/978-3-319-89563-5_3

Faizan, R., Haque, A. U., Cockrill, A., \& Aston, J. (2019). Females at strategic level affecting logistic firms' competitiveness: qualitative comparative analysis of contrasting gender in Pakistan and Canada. Forum Scientiae Oeconomia, 7(1), 57-71. https://doi.org/10.23762/FSO\%20_VOL\%207_NO\%201_4

Girdzijauskaite, E., Radzeviciene, A., \& Jakubavicius, A. (2019). Impact of international branch campus KPIs on the university competitiveness: FARE method. Insights into Regional Development, 1(2), 171-180. https://doi.org/10.9770/ird.2019.1.2(7)

Glistau, E., \& Coello Machado, N. I. (2018). Industry 4.0, logistics 4.0 and materials-chances and solutions. In Materials Science Forum (Vol. 919, pp. 307-314). Trans Tech Publications. https://doi.org/10.4028/www.scientific.net/MSF.919.307 
Haque, A. U., Nair, S. L. S., \& Kucukaltan, B. (2019). Management and administrative insight for the universities: high stress, low satisfaction and no commitment. Polish Journal of Management Studies, 20, 236-255.

Haque, A. U., \& Oino, I. (2019). Managerial challenges for software house related to work, worker and workplace: stress reduction and sustenance of human capital. Polish Journal of Management Studies, 19(1), 170-189. https://doi.org/10.17512/pjms.2019.19.1.13

Haque, A. U., Aston, J., \& Kozlovski, E. (2018). The impact of Stressors on organizational commitment of managerial and non-managerial personnel in contrasting economies: Evidences from Canada and Pakistan. International Journal of Business, 23(2), 166-182.

Hariharasudan, A., \& Kot, S. (2018). A scoping review on Digital English and Education 4.0 for Industry 4.0. Social Sciences, 7(11), 227. https://doi.org/10.3390/socsci7110227

Haseeb, M., Hussain, H. I., Ślusarczyk, B., \& Jermsittiparsert, K. (2019). Industry 4.0: A solution towards technology challenges of sustainable business performance. Social Sciences, 8(5), 154. https://doi.org/10.3390/socsci8050154

Hashemkhani Zolfani, S., Zavadskas, E. K., \& Turskis, Z. (2013). Design of products with both International and Local perspectives based on Yin-Yang balance theory and SWARA method. Economic Research-Ekonomska Istraživanja, 26(2), 153-166. http://doi.org/10.1080/1331677X.2013.11517613

Hofmann, E., \& Rüsch, M. (2017). Industry 4.0 and the current status as well as future prospects on logistics. Computers in Industry, 89, 23-34. https://doi.org/10.1016/j.compind.2017.04.002

Imran, M., Hameed, W., \& Haque, A. U. (2018). Influence of industry 4.0 on the production and service sectors in Pakistan: Evidence from textile and logistics industries. Social Sciences, 7(12), 246. https://doi.org/10.3390/socsci7120246

Kagermann, H. (2015). Change through digitization-Value creation in the age of Industry 4.0. In Management of permanent change (pp. 23-45). Springer Gabler. https://doi.org/10.1007/978-3-658-05014-6_2

Karacay, G., \& Aydin, B. (2018). Internet of things and new value proposition. In A. Ustundag and E. Cevikcan (Eds.), Industry 4.0: managing the digital transformation (pp. 173-185). Springer. https://doi.org/10.1007/978-3-319-57870-5_10

Lasi, H., Fettke, P., Kemper, H. G., Feld, T., \& Hoffmann, M. (2014). Industry 4.0. Business \& Information Systems Engineering, 6(4), 239-242. https://doi.org/10.1007/s12599-014-0334-4

Laužikas, M., \& Miliūte, A. (2020). Human resource management effects on sustainability of high-tech companies: What Lithuania and South Korea can learn from each other. Insights into Regional Development, 2(2), 562-579. https://doi.org/10.9770/IRD.2020.2.2(5)

LeBlanc, D. C. (2004). Statistics: concepts and applications for science (Vol. 2). Jones and Bartlett Publisher.

Li, G., Hou, Y., \& Wu, A. (2017). Fourth Industrial Revolution: technological drivers, impacts and coping methods. Chinese Geographical Science, 27(4), 626-637. https://doi.org/10.1007/s11769-017-0890-x

Lu, Y. (2017). Industry 4.0: A survey on technologies, applications and open research issues. Journal of Industrial Information Integration, 6, 1-10. https://doi.org/10.1016/j.jii.2017.04.005

Magruk, A. (2016). Uncertainty in the sphere of the industry 4.0-potential areas to research. Business, Management and Education, 14(2), 275-291. https://doi.org/10.3846/bme.2016.332

Maresova, P., Soukal, I., Svobodova, L., Hedvicakova, M., Javanmardi, E., Selamat, A., \& Krejcar, O. (2018). Consequences of industry 4.0 in business and economics. Economies, 6(3), 46. https://doi.org/10.3390/economies6030046

Mohelska, H., \& Sokolova, M. (2018). Management approaches for Industry 4.0-the organizational culture perspective. Technological and Economic Development of Economy, 24(6), 2225-2240. https://doi.org/10.3846/tede.2018.6397 
Müller, J. M., Buliga, O., \& Voigt, K. I. (2018). Fortune favors the prepared: How SMEs approach business model innovations in Industry 4.0. Technological Forecasting and Social Change, 132, 2-17. https://doi.org/10.1016/j.techfore.2017.12.019

Nagy, J., Oláh, J., Erdei, E., Máté, D., \& Popp, J. (2018). The role and impact of industry 4.0 and the internet of things on the business strategy of the value chain - The case of Hungary. Sustainability, 10(10), 3491. https://doi.org/10.3390/su10103491

Öztürk, D. (2017). Technological transformation of manufacturing by smart factory vision: industry 4.0. International Journal of Development Research, 7(11), 17371-17382.

Paprocki, W. (2016). Koncepcja Przemysł 4.0 i jej zastosowanie w warunkach gospodarki cyfrowej. In J. Gajewski, W. Paprocki, J., \& Pieregud (Eds.), Cyfryzacja gospodarki i społeczeństwa. Szanse i wyzwania dla sektorów infrastrukturalnych (pp. 39-57) Europejski Kongres Finansowy.

Pereira, A. C., \& Romero, F. (2017). A review of the meanings and the implications of the Industry 4.0 concept. Procedia Manufacturing, 13, 1206-1214. https://doi.org/10.1016/j.promfg.2017.09.032

Petrillo, A., Felice, F. D., Cioffi, R., \& Zomparelli, F. (2018). Fourth industrial revolution: Current practices, challenges, and opportunities. In A. Petrillo, R. Cioff, \& F. De Felice (Eds.), Digital transformation in smart manufacturing (pp. 1-20). https://doi.org/10.5772/intechopen.72304

Plèta, T., Tvaronavičienè, M., \& Della Casa, S. (2020). Cyber effect and security management aspects in critical energy infrastructures. Insights into Regional Development, 2(2), 538-548. https://doi.org/10.9770/IRD.2020.2.2(3)

Prause, G., \& Atari, S. (2017). On sustainable production networks for Industry 4.0. Entrepreneurship and Sustainability Issues, 4(4), 421-431. https://doi.org/10.9770/jesi.2017.4.4(2)

Rao, S. K., \& Prasad, R. (2018). Impact of 5G technologies on smart city implementation. Wireless Personal Communications, 100(1), 161-176. https://doi.org/10.1007/s11277-018-5618-4

Roblek, V., Meško, M., \& Krapež, A. (2016). A complex view of industry 4.0. Sage Open, 6(2), 2158244016653987. https://doi.org/10.1177/2158244016653987

Rodič, B. (2017). Industry 4.0 and the new simulation modelling paradigm. Organizacija, 50(3), 193-207. https://doi.org/10.1515/orga-2017-0017

Rüssmann, M., Lorenz, M., Gerbert, P., Waldner, M., Justus, J., Engel, P., \& Harnisch, M. (2015). Industry 4.0: The future of productivity and growth in manufacturing industries. Boston Consulting Group, 9(1), 54-89.

Saniee, I., Kamat, S., Prakash, S., \& Weldon, M. (2017). Will productivity growth return in the new digital era. Bell Labs Technical Journal, 22, 1-18. https://doi.org/10.15325/BLTJ.2017.2714819

Schmidt, R., Möhring, M., Härting, R. C., Reichstein, C., Neumaier, P., \& Jozinović, P. (2015, June). Industry 4.0-potentials for creating smart products: empirical research results. In International Conference on Business Information Systems (pp. 16-27). Springer. https://doi.org/10.1007/978-3-319-19027-3_2

Schwab, K. (2017). The fourth industrial revolution. Crown Business.

Shpak, N., Odrekhivskyi, M., Doroshkevych, K., \& Sroka, W. (2019). Simulation of innovative systems under Industry 4.0 conditions. Social Sciences, 8(7), 202. https://doi.org/10.3390/socsci8070202

Ślusarczyk, B., \& Haque, A. U. (2019). Public services for business environment: challenges for implementing Industry 4.0 in Polish and Canadian logistic enterprises. Administration \& Public Management Review, (33), 57-76. https://doi.org/10.24818/amp/2019.33-04

Terziyan, V., Gryshko, S., \& Golovianko, M. (2018). Patented intelligence: Cloning human decision models for Industry 4.0. Journal of Manufacturing Systems, 48, 204-217.

https://doi.org/10.1016/j.jmsy.2018.04.019 
Tjahjono, B., Esplugues, C., Ares, E., \& Pelaez, G. (2017). What does industry 4.0 mean to supply chain? Procedia Manufacturing, 13, 1175-1182. https://doi.org/10.1016/j.promfg.2017.09.191

Turskis, Z., Lazauskas, M., \& Zavadskas, E. K. (2012). Fuzzy multiple criteria assessment of construction site alternatives for non-hazardous waste incineration plant in Vilnius city, applying ARAS-F and AHP methods. Journal of Environmental Engineering and Landscape Management, 20(2), 110-120. https://doi.org/10.3846/16486897.2011.645827

Ungerman, O., Dedkova, J., \& Gurinova, K. (2018). The impact of marketing innovation on the competitiveness of enterprises in the context of Industry 4.0. Journal of Competitiveness, 10(2), 132-148. https://doi.org/10.1016/j.promfg.2017.09.191

Yeh, C. C. (2017). Using a hybrid model to evaluate development strategies for digital content. Technological and Economic Development of Economy, 23(6), 795-809.

https://doi.org/10.3846/20294913.2015.1071293

Zavadskas, E. K., Kaklauskas, A., Turskis, Z., \& Kalibatas, D. (2009). An approach to multi-attribute assessment of indoor environment before and after refurbishment of dwellings. Journal of Environmental Engineering and Landscape Management, 17(1), 5-11. https://doi.org/10.3846/1648-6897.2009.17.5-11

Zavadskas, E. K., Turskis, Z., Volvačiovas, R., \& Kildiene, S. (2013). Multi-criteria assessment model of technologies. Studies in Informatics and Control, 22(4), 249-258. https://doi.org/10.24846/v22i4y201301

Zemlickiene, V., \& Turskis, Z. (2020). Evaluation of the expediency of technology commercialization: a case of information technology and biotechnology. Technological and Economic Development of Economy, 26(1), 271-289. https://doi.org/10.3846/tede.2020.11918

Zezulka, F., Marcon, P., Vesely, I., \& Sajdl, O. (2016). Industry 4.0-an introduction in the phenomenon. IFAC-PapersOnLine, 49(25), 8-12. https://doi.org/10.1016/j.ifacol.2016.12.002

Zhou, K., Liu, T., \& Zhou, L. (2015, August). Industry 4.0: Towards future industrial opportunities and challenges. In 2015 12th International Conference on Fuzzy Systems and Knowledge Discovery (FSKD) (pp. 2147-2152). IEEE. https://doi.org/10.1109/FSKD.2015.7382284 